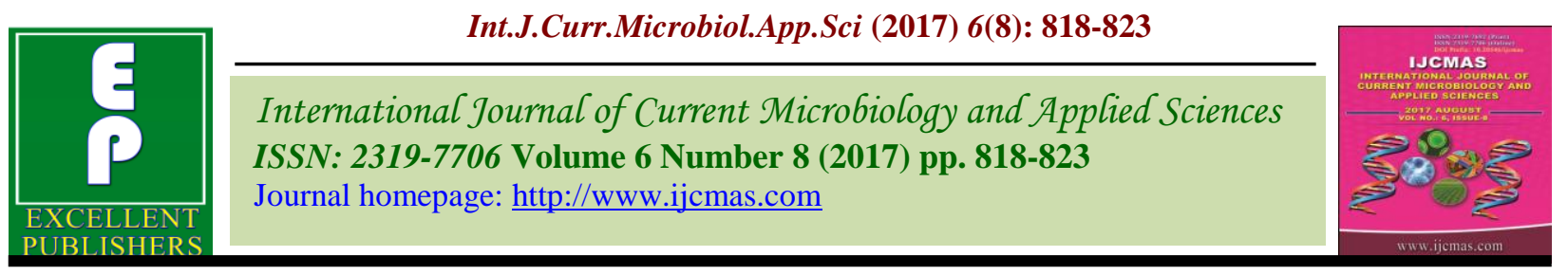

Original Research Article

https://doi.org/10.20546/ijcmas.2017.608.103

\title{
In vitro Screening of Plant Extracts, Trichoderma harzianum and Carbendazim against Fusarium oxysporium f. sp. Lycopersici on Tomato
}

\author{
B. Sreenu* and Sunil Zacharia \\ Department of Plant Pathology, Naini Agricultural Institute, Sam Higginbottom University of \\ Agriculture, Technology and Sciences, Allahabad- 200117, India \\ *Corresponding author
}

A B S T R A C T

\begin{tabular}{|c|c|}
\hline Keywords & \multirow{4}{*}{$\begin{array}{l}\text { Fusarium oxysporum } \mathrm{f} \text {. Sp lycopersici is the causal organism that causes } \\
\text { wilt disease in tomato all over the world. The antifungal activity of aqueous } \\
\text { extract of neem leaf }(5 \%) \text {, ginger bulb }(5 \%) \text {, Lantana camara }(5 \%) \text {, } \\
\text { Trichoderma harzianum }(5 \%) \text {, carbendazim }(0.01 \%) \text { and combination of } \\
\text { carbendazim }+ \text { T. harzianum }(0.01+5 \%) \text { was investigated against Fusarium } \\
\text { oxysporum f. sp lycopersici in vitro. The least growth of pathogen was } \\
\text { recorded in Carbendazim (treated control) }(94.00) \text { followed by Neem leaf } \\
\text { (35.20) followed by Lantana camara }(31.11) \text {, ginger bulb (26.31) and there } \\
\text { was no growth in carbendazim treatment in poison food technique. All } \\
\text { treatments were significantly decrease disease incidence. }\end{array}$} \\
\hline $\begin{array}{l}\text { Carbendazim, } \\
\text { Fusarium } \\
\text { oxysporum f.sp. } \\
\text { Lycopersici, } \\
\text { Neem leaf, } \\
\text { T.harzianum. }\end{array}$ & \\
\hline Article Info & \\
\hline $\begin{array}{l}\text { Accepted: } \\
\text { 14 June } 2017 \\
\text { Available Online: } \\
\text { 10 August } 2017\end{array}$ & \\
\hline
\end{tabular}

\section{Introduction}

Tomato (Lycopersicon esculentum Mill.) is economically one of the most important and popular vegetables throughout the world including India (Neela et al., 2014). Tomato is one of economically the most important vegetable crops in India where it is grown both, indoors and outdoors (Ignjatov et al., 2012). Tomato is the second most important vegetable crop next to potato and generally used in soups and stews (Singh et al., 1980). Globally, tomatoes are grown on in area of 45.2 lakh hectares with a production of 12.4 million metric tonnes. Indian contribution to the world's production was 11.97 million tonnes. Tomato crop was grown in area of
0.59 million hectare with a productivity of 19.97 tonnes per hectare. In Uttar Pradesh it occupied an area of 7600 hectare with an annual production of 92500 tones (Anonymus, 2009). Successful cultivation of tomato is hindered by various diseases. Fusarium wilt is one of the most serious diseases in tomato throughout the world, especially in upland (Charoenporn et al., 2010). Fusarium wilt of tomato caused by Fusarium oxysporum f. sp. lycopersici is a disease that causes serious economic loss. As compared to other plant parasites, fungi have the greatest impact with regard to diseases and crop production losses. In agriculture, 
chemical fungicides are becoming ineffective due to the development of new physiological races of the pathogens (Ocamb et al., 2007). The vegetable growers suffer more than 25.14 $-47.94 \%$ crop losses due to Fusarium wilt of tomato in Uttar Pradesh (Enespa and Dwivedi, 2013).

\section{Materials and Methods}

\section{Evaluation of leaf extracts and fungicide by Poisoned food technique}

Five mm diameter of culture disc of Fusarium was kept at the center of each Petriplate of required concentration dissolved in PDA. Three replications were maintained. The plates were incubated at $27^{\circ} \mathrm{C}$ for ten days and colony diameter was recorded. Per cent inhibition of mycelial growth was calculated by using the formula given by (Vincent, 1947). The readings were taken from 24 to168 hrs after inoculation of the pathogen.

\section{Evaluation of bio-agent by dual culture technique}

Antagonistic microorganism like, Trichoderma harzianum was evaluated for its antagonistic properties against $F$. oxysporum by dual culture technique. Twenty millilitre of PDA was poured into sterile Petriplates. Fungal antagonist was evaluated by inoculating the pathogen at one side of the Petriplate and the antagonist inoculated at exactly opposite side of the same plate by leaving 3-4 cm gap. For this actively growing cultures were used. One control was maintained where in only test fungus was grown (Sundaramoorthy and Balabaskar, 2013). The treatments were replicated three times. The plates were incubated for seven days at $27 \pm 1^{\circ} \mathrm{C}$. After incubation, the colony diameter of $F$. oxysporum was recorded. Per cent inhibition was calculated by using the formula given by Vincent (1947).

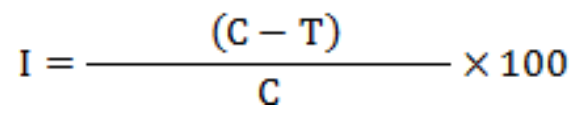

Where,

$\mathrm{PI}=$ Per cent inhibition over control

$\mathrm{C}=$ Growth of test pathogen with absence of antagonist ( $\mathrm{mm})$.

$\mathrm{T}=$ Growth of test pathogen with antagonist (mm).

\section{Results and Discussion}

The initial day growth least radial growth of Fusarium oxysporum f. sp. lycopersici was observed in $\mathrm{T}_{2}$ Neem leaf $(5.33 \mathrm{~mm})$ followed by $\mathrm{T}_{4}$ Lantana camara $(5.66 \mathrm{~mm})$, and $\mathrm{T}_{3}$ Ginger bulb $(6.16 \mathrm{~mm})$ as compared to the treated check $T_{1}$ carbendazim (0) and untreated check $\mathrm{T}_{0}(7.33 \mathrm{~mm})$. Among the treatments $\left(\mathrm{T}_{0}\right), \quad\left(\mathrm{T}_{3}\right), \quad\left(\mathrm{T}_{4} \mathrm{~T}_{2}\right), \quad\left(\mathrm{T}_{1}\right)$ are statistically non-significant at par with each other at 24 hours of inoculation. The final day radial growth of Fusarium oxysporum f. sp. Lycopersici was observed in $\mathrm{T}_{2}$ Neem leaf $(29.16 \mathrm{~mm})$ followed by $\mathrm{T}_{4}$ Lantana camara (31.00 mm), $\mathrm{T}_{3}$ Ginger bulb (33.16 $\left.\mathrm{mm}\right)$ as compared to the treated check $\mathrm{T}_{1}$ carbendazim (0) and untreated check $\mathrm{T}_{0}(45.00 \mathrm{~mm})$. At 144 hours of inoculation the treatments (T0), $\left(\mathrm{T}_{3}\right),\left(\mathrm{T}_{4}\right),\left(\mathrm{T}_{2}\right)$ are statistically non-significant at par with each other.

Maximum per cent inhibition of radial mycelial growth of Fusarium oxysporum $\mathrm{f}$. sp. lycopersici was observed in $\mathrm{T}_{2}$ Neem leaf (35.20\%) followed by $\mathrm{T}_{4}$ Lantana camara (31.11\%), $\mathrm{T}_{3}$ Ginger bulb (26.31\%), as compared to the treated check $\mathrm{T}_{1}$ carbendazim $(94.00 \%)$ and $\mathrm{T}_{0}$ untreated check $(0 \%)$. However, the treatments were significant and statistically at par with each other. Minimum average radial growth of Trichoderma harzianum against Fusarium oxysporum was observed in $\mathrm{T}_{1}$ Trichoderma harzianum (6.50 $\mathrm{mm}$ ) followed and compared by $\mathrm{T}_{0}$ control $(7.33 \mathrm{~mm})$. Among the treatments $\left(\mathrm{T}_{1} \mathrm{~T}_{0}\right)$ are 
statistically non-significant at par with each other at 24 hours of inoculation. Minimum average radial growth of Trichoderma harzianum against Fusarium oxysporum was observed in $\mathrm{T}_{1}$ Trichodermaharzianum $(9.83$ $\mathrm{mm}$ ) followed and compared by $\mathrm{T}_{0}$ control $(13.67 \mathrm{~mm})$. Among the treatments $\left(\mathrm{T}_{1} \mathrm{~T}_{0}\right)$ are statistically non-significant at par with each other at 48 hours of inoculation (Tables 1, 2 and 3 ).

Table.1 Efficacy of leaf extracts and carbendazim against

Fusarium oxysporum f. sp. lycopersici by poison food technique

\begin{tabular}{|c|c|c|c|c|c|c|c|}
\hline \multirow[t]{2}{*}{ S/N. } & \multirow[t]{2}{*}{ Treatments } & \multicolumn{6}{|c|}{$\begin{array}{l}\text { Radial growth (mm) of Fusarium oxysporum f. sp. } \\
\text { Lycopersici }\end{array}$} \\
\hline & & 24 hrs & 48 hrs & $72 \mathrm{hrs}$ & $96 \mathrm{hrs}$ & $120 \mathrm{hrs}$ & $144 \mathrm{hrs}$ \\
\hline $\mathrm{T}_{1}$ & $\begin{array}{l}\text { Carbendazim } \quad \text { (Treated } \\
\text { check) }\end{array}$ & 0.00 & 0.00 & 0.00 & 0.00 & 0.00 & 0.00 \\
\hline $\mathrm{T}_{2}$ & Neem leaf & 5.33 & 9.00 & 13.50 & 17.66 & 22.83 & 29.16 \\
\hline $\mathrm{T}_{3}$ & Ginger bulb & 6.16 & 10.33 & 15.66 & 21.33 & 27.00 & 33.16 \\
\hline $\mathrm{T}_{4}$ & Lantana camara & 5.66 & 9.16 & 15.00 & 20.16 & 25.50 & 31.00 \\
\hline $\mathrm{T}_{0}$ & Control (untreated check) & 7.33 & 11.50 & 18.16 & 25.00 & 33.00 & 45.00 \\
\hline \multicolumn{2}{|c|}{ F-test } & $\mathbf{S}$ & $\mathbf{S}$ & $\mathbf{S}$ & $\mathbf{S}$ & $\mathbf{S}$ & $\mathbf{S}$ \\
\hline \multicolumn{2}{|c|}{$\mathbf{S} \mathbf{E} \mathbf{m}=$} & 0.14 & 0.21 & 0.44 & 0.50 & 0.56 & 0.38 \\
\hline \multicolumn{2}{|c|}{ CD (5\%) } & 0.47 & 0.66 & 1.38 & 1.57 & 1.78 & 1.19 \\
\hline
\end{tabular}

Table.2 Per cent inhibition of radial mycelial growth of Fusarium oxysporum as affected by treatments

\begin{tabular}{|c|c|c|}
\hline Treatment No & Treatments & Inhibition Percentage \\
\hline $\mathrm{T}_{1}$ & Carbendazim (treated control) & 94.00 \\
\hline $\mathrm{T}_{2}$ & Neem leaf & 35.20 \\
\hline $\mathrm{T}_{3}$ & Ginger bulb & 26.31 \\
\hline $\mathrm{T}_{4}$ & Lantana camara & 31.11 \\
\hline $\mathrm{T}_{0}$ & Control (untreated check) & 0.00 \\
\hline \multirow[t]{3}{*}{ F- test } & & $\mathrm{S}$ \\
\hline & S. Ed. $( \pm)$ & 0.32 \\
\hline & C. D. $(P=0.05)$ & 1.03 \\
\hline
\end{tabular}


Table.3 Mycelial growth (mm) of Fusarium oxysporum f. sp. lycopersici as affected by Trichoderma harzianum (dual culture technique)

\begin{tabular}{|c|c|c|c|c|c|c|c|}
\hline \multirow[t]{2}{*}{$\mathbf{S} / \mathbf{N}$. } & \multirow[t]{2}{*}{ Treatments } & \multicolumn{6}{|c|}{$\begin{array}{l}\text { Radial growth (mm) of Fusarium oxysporum f. sp. } \\
\text { lycopersici }\end{array}$} \\
\hline & & 24 hrs & $48 \mathrm{hrs}$ & $72 \mathrm{hrs}$ & 96 hrs & $120 \mathrm{hrs}$ & 144 hrs \\
\hline $\mathrm{T}_{\mathbf{1}}$ & Trichoderma harzianum & 6.50 & 9.83 & 15.33 & 24.00 & 34.33 & 34.00 \\
\hline $\mathrm{T}_{\mathbf{0}}$ & Control (untreated check) & 7.33 & 13.67 & 23.50 & 28.17 & 36.50 & 38.00 \\
\hline & F-test & NS & NS & $\mathbf{S}$ & NS & NS & NS \\
\hline & $\mathbf{S} \mathbf{E} \mathbf{m}=$ & 0.236 & 1.70 & 1.95 & 1.28 & 1.99 & 1.80 \\
\hline & CD $(5 \%)$ & 0.925 & 6.69 & 7.66 & 5.02 & 7.82 & 7.07 \\
\hline
\end{tabular}

Plate.1 Growth of Fusarium oxysporumin food poison technique at 144 hours
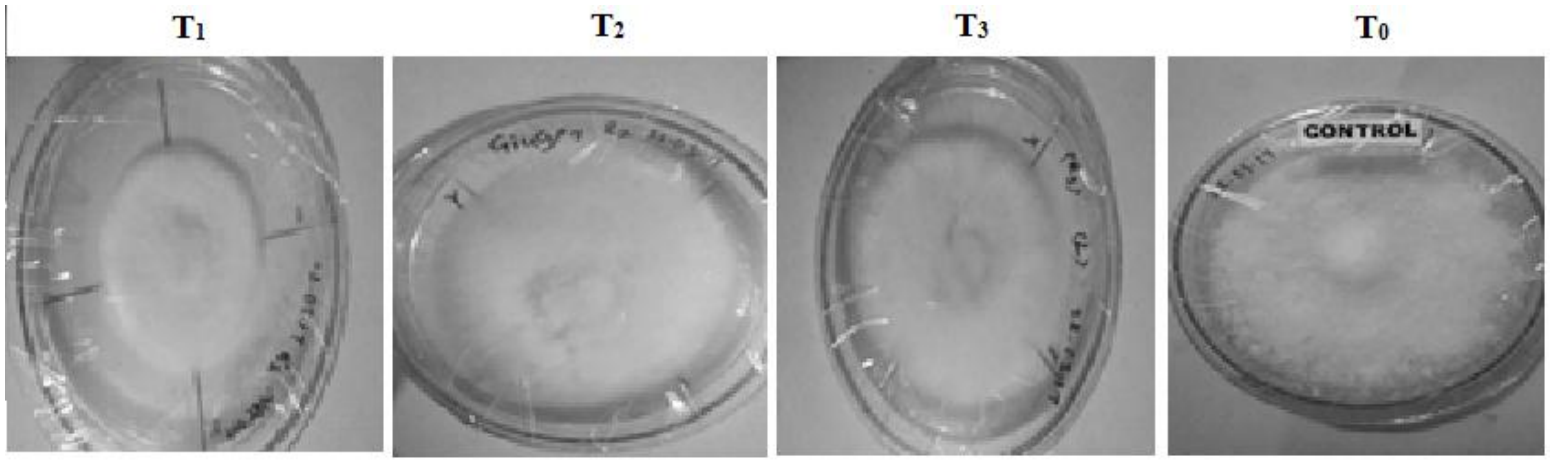

Plate.2 Evaluation of the antagonistic activity of $T$. harzianum on $F$. oxysporium in dual culture technique

$\mathbf{T}_{1}$

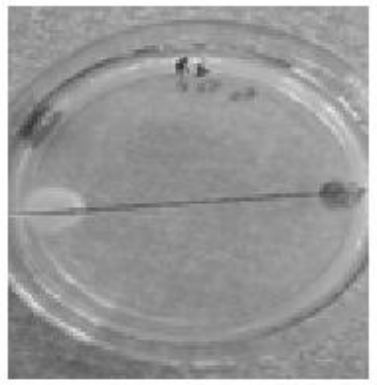

24 hours

Sundaramoorthy and Balabaskar (2013) also reported that $T$. harzianum (ANR-1) isolate exhibited least disease incidence (15.33\%) among the fifteen Trichoderma isolates under in vitro. Rahmah et al., (2013) also reported that Lantana camera and Zizipusspina-christi
$\mathbf{T}_{1}$

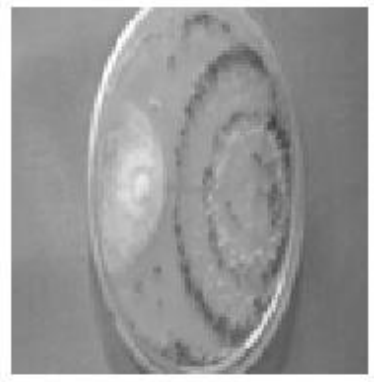

$\mathbf{T}_{0}$

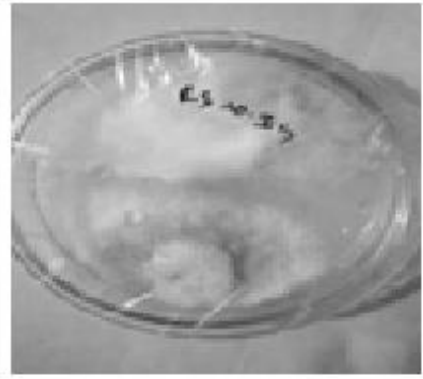

144 hours

were not effective against soil borne fungi of tomato (Fusarium oxysporium, Pythium aphanidermatum and Rhizoctonia solani) under lab condition. Ali et al., (2013) found that Aloe-vera was most effective one in inhibiting the mycelial growth of F.o. f.sp. 
pisi followed by Lantana camera (50.09\%). Sultana and Ghaffar (2013) reported that benlate and carbendazim completely inhibited the mycelial growth of Fusarium oxysporuium @ 100ppm in poisoned food technique.

Our results are in agreement with Addullah et al., (2013) who reported that carbendazim treatment recorded lowest disease severity (16.9\%) followed by $T$. harzianum $(15.10 \%)$ and Neem leaf extract $(20.70 \%)$ under pot condition.

Bokkhari et al., (2008) reported that soil application of T.harzianum and Topsin-M showed that zero and $0.74 \%$ disease intensity respectively. Kouki et al., (2012) revealed that Trichoderma harzianum (N-8) isolate showed stimulatory effect on the plant height $(70.13 \mathrm{~cm})$ and dry weight $(265.42 \mathrm{~g})$ in comparison to control $(54.6 \mathrm{~cm}$ and $195.5 \mathrm{~g})$.

Sundaramoorthy and Balabaskar (2013) who reported that the isolates of Trichoderma harzianum significantly enhanced seed germination, reduced disease incidence and promoted plant growth of tomato as compared to control.

\section{References}

Abdalla, M. and Alwany, E. 2014. Efficacy of Salicylic Acid \& 2, 6Dichloroisonicotinic Acid as Systemic Acquired Resistance Activators In vitro on Fusarium oxysporumf. sp. lycopersici and Fusarium oxysporum $\mathrm{f}$. sp. radicis-cucumerinum Radial Growth. Nature and Sci., 12(9).

Ali, M., Lal, M., Khan, A., Singh, V. and Singh, P.S. 2013. Evaluation of leaf extracts and essential oils against Fusarium oxysporum f.sp. pisi the causal agent of pea wilt, Indian Phytopath., 66(3): 316-318.
Anonymous. 2011. National Horticulture Board, Ministry of Agriculture Government of India. 181-182 Pp.

Bokhari, A.A., Sahi, S.T., Khan, M.A., Ahmad, R. and Din, I. 2008. In vivo Studies on the Biological and Chemical control of Guava Decline caused by Different soil born Pathogen. Pak. J. Agri. Sci., Vol. 45(1).

Chaudhary, K., Singh, S.R., Singh, A.K. and Mala, S. 2013. Evaluation of Fungicides, Botanicals, Neem products and Bio-agents against Wilt of Pigeonpea caused by Fusarium udam. Butler, Multidisciplinary Adv. Res., Vol. 2(2): 01-06.

Enespa, Dwivedi, S.K. 2013. In vitro efficacy of some fungal antagonists against fusariiumsolani and Fusarium oxysporum f. sp. lycopersici causing brinjal and tomato wilt. Int. J. Biol. Pharm. Res., 4: 46-52.

Ignjatov, M., Dragana, M., Nikolić, Z., Gvozdanović, J., Jovičić, V., Dušica, and Zdjelar, G. 2012. Fusarium oxysporum as Causal Agent of Tomato Wilt and Fruit Rot, Pestic. Phytomed., (Belgrade), 27(1).

Kouki, S., Saidi, N., Rajeb, A. B., Brahmi, M., Bellila, A., Fumio, M., Hefiene A., Jedidi, N., Downer, J., Ouzari, H. 2012. Control of Fusarium Wilt of Tomato Caused by Fusarium oxysporum f. sp. Radicis- Lycopersici Using Mixture of Vegetable and Posidonia oceanica Compost. Appl. Environ. Soil Sci., Volume 2012, Article ID 239639.

Neela, F.A., Sonia, I.A., Shamsi, S. 2014. Antifungal Activity of Selected Medicinal Plant Extract on Fusarium oxysporum Schlechtthe Causal Agent of Fusarium Wilt Disease in Tomato. American J. Plant Sci., 5: 2665-2671.

Ocamb, C.M., Hamm, P.B. and Johnson, D.A. 2007. Benzimidazole resistance of Fusarium species recovered from 
potatoes with dry rot from storages located in the Columbia basin of Oregon and Washington. American $J$. Potato Res., 84: 169-177.

Rahmah, A.N., Mostafa, A.A., AbdelMegged, A., Yokout, S.M. and Hussein, S.A. 2013. Fungicidal activity of certain methanolic plant extracts against tomato phytopathogenic fungi. African $J$. Microbiol., 7(6): 517-524.

Singha, I.M., Kakoty, Y., Unni, B.G., Kalita, M.C., Das, J., Naglot, A., Wann, S.B. and Singh, L. 2011. Control of Fusarium wilt of tomato caused by Fusarium oxysporum f. sp. lycopersici using leaf extract of Piper betle L.: a preliminary study. World J. Microbiol. Biotechnol., doi: 10.1007/s11274-011-
0730-6.

Sultana, N. and Ghaffar, A. 2013. Effect of Fungicides, Microbial antagonists and oil cakes in the control of Fusarium oxysporum, the cause of seed rot and root infection of bottle gourd and cucumber. Pak. J. Bot., 45(6): 21492156.

Sundaramoorthy, S. and Balabaskar, P. 2013. Biocontrol efficacy of Trichoderma spp. against wilt of tomato caused by Fusarium oxysporum f. sp. lycopersici, Appl. Biol. Biotechnol., Vol. 1(03), pp. 036-040.

Vincent, J.M. 1974. Distortion of fungal hyphae in the presence of certain inhibitors. Nature, 159: 239-241.

\section{How to cite this article:}

Sreenu, B. and Sunil Zacharia. 2017. In vitro Screening of Plant Extracts, Trichoderma harzianum and Carbendazim against Fusarium oxysporium f.sp. Lycopersici on Tomato. Int.J.Curr.Microbiol.App.Sci. 6(8): 818-823. doi: https://doi.org/10.20546/ijcmas.2017.608.103 